This is an Open Access article distributed under the terms of the Creative Commons Attribution 4.0 International License which permits unrestricted non-commercial use, distribution, and reproduction in any medium, provided the original work is properly cited.

http://ijnms.net/index.php/ijnms

\title{
RELATIONSHIP BETWEEN NURSE CHARACTERISTICS WITH DISCHARGE PLANNING IMPLEMENTATION
}

\author{
Ana Zakiyah*, Duwi Basuki**, Windu Santoso*** \\ Maternity of Nursing STIKES BINA SEHAT PPNI
}

\section{ABSTRACT}

Discharge planning was one of the activities in the provision of nursing care on patients in the hospital, it would have a shortening impact on patient care in the hospital and reduced the patient's recurrence rate, but the implementation was not appropriate. So far, implementation of discharge planning was still to be done after the patient finished having treatment by making a summary of the recording of patients return. Various characteristic factors of nurses can influence the implementation of discharge planning in hospital. The research purpose was to know the relationship of factors that influence discharge planning with the implementation of discharge planning. The research design used was cross-sectional, the instrument used was the questionnaire about the characteristics of the nurses and the implementation of discharge planning. The population of research was nurses who served in the inpatient room RSI Sakinah Mojokerto number of 80 nurses and obtained the number of 67 samples with proportional random sampling technique. The result of analysis with Pearson correlation for age, education, length of work and chi-square for marital status showed that the characteristics of nurses related to discharge planning implementation were an educational factor with $\mathrm{p}$-value 0,023 . The higher the nurse education caused more critical, logical and systematic in thinking to improve the quality of its work and the greater the desire to utilize the knowledge and skills it possesses
Keywords

Discharge

Planning,

Nurses,

Education 


\section{INTRODUCTION}

Facility of health services is one of the expectations of patients to look for healing. Therefore the quality of health care will greatly determine patient satisfaction in seeking healing. The quality of nursing care can be improved through the application of discharge planning.

Discharge planning according to the National Council of Social Service / NCSS (2006) is the goal of care planning by empowering clients on making decisions and working to optimize the potential of life independently through the support and resources available in the family or community. The discharge planning process is carried out since the patient to be admitted to the health service, especially in the hospital so that the patient's time is shorter to stay. Effective discharge planning involves continuous assessment to obtain comprehensive information about the dynamic patient needs, the statement of nursing diagnosis, planning to ensure the patient's needs are consistent with what the health provider is doing (Kozier, 2004).

Discharge planning is the duty and responsibility of nursing staff. This is by the results of research from Tomura et al. (2011) stating that the process of home patient planning is done by the nurse. Discharge planning of the patient should be carried out with optimal duration for the client and started after admission to the hospital (Baron et al., 2008).

The results of the interview on October 16, 2015, with the nurses in Gunung Jati room that the discharge planning had been carried out by the nurses, but only when the patient finished undergoing treatment in the form of explanation of home instructions and documentation in the form of patient summary home. The results of observations made on October 18, 2015, the planned return of patients was done if the doctor/team of doctors have agreed to go home / have done visite conclude that the patient was allowed to go home. After that, a new patient's family was called to be given an education about what to do with the patient. It conveys, among other things, on the schedule of further controls, regular medication schedule, and dietary arrangements by the summary file back home.

The results of research that had been done Poglitsch, Emery \& Darragh (2011) was about the determinants of the success of the discharge planning process consists of five contributing factors. These factors were personnel discharge planning factors, involvement, and participation, communication, time, agreement and consensus. Personnel factors were factors derived from human resources related to the characteristics attached to the nurse and affect the implementation of discharge planning.

Early discharge planning of patients will have an impact on shortening the length of patient care at the hospital. It can have an impact on the reduction of costs to be incurred by the hospital. Another impact is that it can reduce the rate of recurrence after the client returns from the hospital, allowing the intervention of the return plan to be done on time (Swanburg, 2000; Birmingham, J. 2010).

An improper discharge planning could have an impact on the return of the patient from the hospital after the patient has finished the treatment and ultimately the patient will increase the financing to undergo 
hospitalization back at the hospital. Patients requiring home care, health counseling or health counseling but not assisted by hospital nurses before client return will result in the return of patients to hospitalization (Potter \& Perry, 2005). Based on the exposure, the researcher wanted to know the correlation between characteristic nurse factor and discharge planning.

\section{METHOD}

The method of research used crossectional. The population was all the nurses who served in inpatient room RSI Sakinah Mojokerto amounted to 80. Samples were taken by nonprobability sampling method was proportional random sampling and got 67 samples. The study was conducted from January to July 2017

The research instrument used a questionnaire containing the characteristics of nurses that include age, gender, education, marital status, and length of work. While the discharge planning questionnaire was developed based on the theory of NCSS (2006), Moran, et al. and Tomura et al. (2011). Data analysis in this study includes univariate and bivariate. Age, length of work and education using Pearson Correlation, but marital status using chisquare so that the factors related to discharge planning are obtained.

\section{RESULTS}

\section{Characteristics of the nurs}

Table 1. Characteristics of the nurse

\begin{tabular}{|c|c|c|c|c|}
\hline No & Variable & Kategori & Jumlah & $\begin{array}{c}\text { Prosentase } \\
(\%)\end{array}$ \\
\hline \multirow[t]{2}{*}{1} & Gender & Man & 24 & 48 \\
\hline & & Woman & 30 & 52 \\
\hline \multirow[t]{3}{*}{2} & Education & Diploma & 30 & 56 \\
\hline & & 3 nursing & 24 & 44 \\
\hline & & Ners & & \\
\hline \multirow[t]{2}{*}{3} & Marital & Married & 15 & 20 \\
\hline & status & Not married yet & 39 & 80 \\
\hline \multirow[t]{4}{*}{4} & Age & 1. $20-25$ & 18 & 33 \\
\hline & & 2. $26-30$ & 14 & 26 \\
\hline & & 3. $31-35$ & 20 & 37 \\
\hline & & 4. $36-40$ & 2 & 4 \\
\hline \multirow[t]{5}{*}{5} & Working & 1. <1 year & 10 & 19 \\
\hline & period & 2. 1-5 years & 21 & 39 \\
\hline & & 3. 6-10 years & 21 & 39 \\
\hline & & 4. $11-15$ & 2 & 3 \\
\hline & & years & & \\
\hline
\end{tabular}

Nurse executor in this research by gender of the majority of woman that was 30 nurse (52\%). Judging from the educational background of nursing executor was dominated by D3 nursing that was 30 nurses $(56 \%)$. Based on age, nurses aged 31-35 years were 20 nurses (30\%), and nursing periods between 1-5 and 6-10 years were 21 nurses $(39 \%)$, respectively.

\section{Implementation of discharge planning}

Table2. Implementation of discharge planning

\begin{tabular}{|c|c|c|c|c|}
\hline No & Variabel & Kategori & Jumlah & $\begin{array}{c}\text { Prosentase } \\
(\%)\end{array}$ \\
\hline \multirow[t]{6}{*}{1} & Implementation & Bett & 19 & 35 \\
\hline & of discharge & er & 21 & 39 \\
\hline & planning & Goo & 14 & 26 \\
\hline & & $\mathrm{d}$ & & \\
\hline & & Bad & & \\
\hline & & & 54 & $100 \%$ \\
\hline
\end{tabular}


Analysis of factors to discharge planning

\begin{tabular}{lr}
\hline \multicolumn{1}{l}{ Nursing characteristics factor } & P value \\
\hline Gender & 0,083 \\
& \\
\hline Education level & $0,023^{*}$ \\
\hline Working period & 0,602 \\
& \\
\hline Marital status & 0,538
\end{tabular}

*meant to $\alpha: 0,05$

Table analysis of factors to discharge planning

\section{DISCUSSION}

The results showed that nurse education was greater than that of nursing educated D3 nursing. The result of bivariate analysis found that there was a positive correlation between education level and discharge planning implementation. Implementation of planning is a form of the performance of nurses in the provision of nursing care.

Education was one of the demographic characteristics that can affect a person, both on the environment and certain objects. Also education is an indirect factor that affects the performance (Ilyas, 2002). The higher the education will be more critical, logical and systematic in thinking to improve the quality of its work. In line with the opinion of Siagian (2006) which suggests that the higher a person's education, the greater the desire to utilize the knowledge and skills he has. With many vocational education nurses, the hospital management must constantly commit to improving its human resources by improving the qualification of professional nurse education that is News level. Hospital nurses include the majority of the total staff in hospitals, so by paying close attention to nurses in hospitals, especially the improvement of education, it will likely have an impact on the improvement of professional nursing services.

Nurses who were educated D3 Nursing perform discharge planning more than nurses with S1 / News education. This S1 / News educated nurse was possible as head of space, while the role of head is the management of service management so that in discharge planning a head of space does not directly conduct discharge planning. Thus, the nursing nurse of D3 nursing who was positioned as the team leader and the nurse of the executive, the discharge planning implementation becomes their responsibility.

\section{CONCLUDE}

Nurse education was related to discharge planning in the hospital. The higher the nurse education will cause the nurses to be more critical, logical and systematic in thinking, and can improve the ability of nurses in perceiving their role so that in the end can improve the quality of their work.

\section{SUGGESTION}

For the Nursing Manager

Conducting a workshop on standardization of discharge planning for health personnel in the hospital.

Developing in-house training program for nurses about discharge planning of patients.

Developing monitoring and evaluation program in discharge planning of patient.

Creating a nurse education enhancement program

For Nurses

Improving performance in discharge planning 
Motivating to conduct professional relationships with colleagues, doctors, patients and families, and health workers in the community in discharge planning

\section{REFERENCE}

Baron, M., Erlenbusch, B., Moran, C.F., O'Connor, K., Rice, K., \& Rodriguez, J.. (2008). Best practices manual for discharge planning: Mental health \& substance abuse facilities, hospitals, foster care, prisons and jails. Los Angeles: Coalition to hunger \& homelessness.

Birmingham, J. (2010). Discharge planning guide tool for compliance. Third edition. United Sates of America: HCPro. Inc.

Ilyas, Y. (2002). Kinerja, teori, penilaian dan penelitian. Cetakan ketiga. Jakarta: Pusat Kajian Ekonomi Kesehatan. FKM UI.

Moran, G., Semansky, R., Quinn, E., Noftsinger, R., \& Koenig, T. (2005). Evaluability assessment of discharge planning and the prevention of homelessness. Rockville, Maryland: WESTAT.

NCSS. (2006). Care and discharge planning: A guide for service providers. Serial No:
032/SDD19/DEC06. Singapore: National Council of Social Service.

Poglitsch, L.A., Emery, M., \& Darragh, A. (2011). A qualitative study of the determinants of successful discharge for older adult inpatients. Journal of American Physical Therapy Association. (ISSN 15386724).

Potter, P.A. \& Perry, A.G. (2005). Buku ajar fundamental keperawatan: Konsep, proses dan praktik. Volume 1. Alih bahasa Yasmin Asih, et al. Editor edisi bahasa Indonesia Devi Yulianti, Monica Ester. Edisi 4. Jakarta: EGC.

Siagian, S.P. (2006). Teori dan praktek kepemimpinan. Cetakan kelima. Jakarta : P.T Rhineka Cipta.

Swansburg, R.C. (2000). Pengantar kepemimpinan dan manajemen keperawatan. Alih bahasa Suharyati Samba. Editor Monica Ester. Jakarta: EGC.

Tomura, H., Yamamoto, M.N., Nagata, Murashima, S., \& Suzuki, S. (2011). Creating an agreed discharge: discharge planning for clients with high care needs. $J$ Clin Nurs. PubMed. 2011 Feb; 20 (3-4): 44453. Doi: $10.1111 / \mathrm{j} .1365-$ 2702.2010.03556.x.

PMID: 21219523. 